\title{
Enhancing Elementary Level EFL Students' Reading Comprehension and Writing Skills through Extensive Reading Enrichment Program
}

\author{
Rania Adel Ibrahim Ahmed (Corresponding author) \\ Institute of Educational studies, Department of Curriculum and Instruction \\ Cairo University, Cairo, Egypt \\ Tel: 20-100-985-5699Ｅ-mail: rania.ahmad.efl@outlook.com \\ Hussam Rajab \\ English Language Institute, King Abdulaziz University, Jeddah, Saudi Arabia \\ Tel: 966-559802922Ｅ-mail: hmrajab@kau.edu.sa
}

Received: May 24, 2015 Accepted: June 4, 2015 Published: June 4, 2015

doi:10.5296/ijele.v3i2.7742 URL: http://dx.doi.org/10.5296/ijele.v3i2.7742

\begin{abstract}
This quasi-experimental, longitudinal, quantitative study investigated the impact of Extensive Reading (ER) on developing second language (L2) reading comprehension and writing skills among primary school EFL learners in two Arab countries, Egypt and Saudi Arabia. The study is based on an experiment conducted over a nine-month period on a convenience sample of 112 primary school students $(n=112)$ divided into five groups, three experimental groups and two control group, where the students belonged to two different private schools in Egypt and two different international schools in two cities in Saudi Arabia. The experiment, in the form of an enrichment ER program, used graded readers for young learners and was designed to foster ER for pleasure. The study, guided by three hypotheses, incorporated two types of statistical analysis tests, paired samples t-tests and one-way analysis of variance (ANOVA). The statistical analysis tests performed indicated marked improvement in English proficiency in the two experimental groups, with particular reference to reading comprehension and writing. A number of pedagogical implications and recommendations for future research are given. Additionally, the study highlights the issue related to insufficient exposure to English for young Arab EFL learners in their daily lives, which, unfortunately, seems to cause relapses in their L2 intake, despite having an age advantage.
\end{abstract}

Keywords: Extensive Reading. Reading Comprehension. Young Learners. EFL. Input Hypothesis. 


\section{Introduction}

\subsection{Background into Reading}

Several definitions exist for reading in the literature. However, most of these definitions seem to stress one common factor and that is the metacognitive feature of reading. As such, some researchers view reading as a complex structure of patterns of higher mental thinking which involves all types of thinking such as: evaluating, judging, imagining, reasoning and problem-solving (Gates, 1949). Barnett (1989) however, believes reading to be involving an interdisciplinary insights from which, different fields of study such as psychology, sociology, education, and theoretical and applied linguistics, are connected. Other researchers believe it to be a process of formulating in image of a written text in the mind of the reader before the contents of a particular text are comprehended (Richards, Plat and Plat, 1999).

Reading is considered a basic life skill, the lack of which can affect the student's academic growth and success (Pugh, Pawan, and Antommarchi, 2000). Lyons (2003) states that: "learning to read is critical to students' academic success and has a tremendous impact on their emotional and social development throughout life" (p.2). It is the main foundation upon which, a child's success in school and subsequently, throughout life, depends on. However, many children do not seem to grasp these skills early enough in their lives and as a result, struggle with rudimentary reading skills (Lyons and Weiser, 2009). Furthermore, students who do not receive early assistance in reading, are likely to miss out on the vital, intelligence-boosting properties of literacy (Ritchie, 2014). Neglecting the reading skill in children's early lives can have adverse effect on their academic achievements, namely difficulties in being motivated to read in various academic disciplines. Rasinski and Hoffman, (2003) warn: "Reading difficulties are the most frequent learning problem among students and the main reason for academic failure" (p. 43). Additionally, reading is considered a vital pathway to the development of personality traits as well as the development of social, economic and civic life (Holden, 2004). It is perceived as a sign of a literate and educated society (Roe, Smith and Burns, 2011) and some researchers believe that successes in life such an employment and quality of life can be attributed to the level of reading ability of a particular person (Allor, Mathes, Roberts, Cheatham, and Otaiba, 2014). Additionally, Mokhtari \& Shoerey (2008) note that an individual who is well-educated, has to have the ability to read professionally. Reading is one of the ways people around the world can increase their knowledge as well as get exposed to the experiences of other people. Krashen (1993) summarises the importance of reading by stating:

"When children read for pleasure, when they get "hooked on books", they acquire, involuntarily and without conscious effort, nearly all of the so-called "language skills" many people are so concerned about: they will become adequate readers, acquire a large vocabulary, develop the ability to understand and use complex grammatical constructions, develop a good writing style, and become good (but not necessarily perfect) spellers. Although free voluntary reading alone will not 
ensure attainment of the highest levels of literacy, it will at least ensure an acceptable level. Without it, I suspect that children simply do not have a chance". (p.85)

\subsection{Reading in English as a Foreign Language (EFL) Context}

Language wise, reading is believed to possibly be one of the most realistic communicative skills that occur in an English as a foreign language (EFL) classroom (Mikulecky and Jeffries, 1986). Krashen (2004) asserts that reading is one of the most effective ways for L2 learners to acquire language skills in context and many researchers believe reading to be the most important of the four main skills of English language learning (ELL) (Koch 1974, Alderson 1984, Carrell and Carrell 2006 ). However, reading as a language skill is considered both a complex and a difficult skill compared to the other main skills such as listening, speaking, and writing since it is the skill that connects the other skills. Mclaughlin (1987) asserts that of all the language skills that a child must acquire, reading is considered the most difficult and complex one. This is due to the fact that reading in a foreign language is concerned with decoding texts in that foreign language and deriving meaning from print (Carrel, 1995). Some researchers, though accept that reading is a heavily cognitive process, do not see reading as a bottom-up process and thus, viewing reading as an entirely decoding process can be problematic for second language (L2) learners since they will only read individual words without formulating an overview of the whole text (Barnett, 1989). As such, advocates of the top-down process model believe the reader to be an active participant who is cognitively able to make predictions, process information and, at the same time, use background linguistic knowledge as well as the background knowledge of the content area and the rhetorical structure of the text in order to comprehend it in a foreign language (Carrell, 1995). Whether it is a top-down or bottom-up process, researchers believe reading in a second language (L2) to be generally a much slower process than reading in the first language (L1) and predictably, results in slower comprehension than what is expected with L1 readers (Alderson \& Urquhart, 1984; Alhaqbani \& Riazi, 2012). Thus, it is important for EFL teachers at all age groups to be aware of the processes that are involved in reading and how reading can be taught and developed in an EFL context (Weaver, 2002). In particular, EFL teachers of primary school students need to have the expertise and skills in order to be able to engage their students with fun and enjoyable experiences of learning a second language in general and reading in particular.

\subsection{Extensive Reading in the EFL Context}

Several research studies have shown the effectiveness of ER in the English as a second language (ESL) and as a foreign language (EFL), contexts (Bamford \& Day, 1998; Bell, 2001; Krashen \& Mason, 1997). The early part of the 20th century witnessed a wave of resurgence of interest in extensive reading, perhaps as a result of insights from second language acquisition (SLA) studies into the role and nature of input in the learning process (Hedge, 2003) as well as the ease with which extensive reading might be implemented (Bamford \& Day, 2004; Nakanishi, 2005). Thus, there is a large body of research that would posit that ER results in students' making significant gains in other aspects of foreign language competence 
such as listening, speaking, writing, and vocabulary (Nation, 1997 and Bamford and Day, 1998). Some researchers believe that ER may lead to increased reading rate and reading comprehension (Elley \& Mangubhai, 1983; Bell, 2001; Iwahori, 2008;) and in addition, ER has been shown to enhance students' writing skill (Elley and Mangubhai, 1981; Janopolous, 1986; Robb and Susser, 1989; Hafiz and Tudor, 1990; Tsang, 1996; Mason and Krashen, 1997; Hedgcock and Atkinson, 1998; Grabe, 2010) and also, motivates learners to improve their reading and writing in L2 (Yu and Wong, 1991). Recently, a strong relationship has been found to exist between the reading speed and the reading comprehension in both L1 as well as L2 (Beglar, Hunt and Kite, 2012).

Numerous definitions exist in the literature for ER. Amongst the early definitions is one that describes ER as reading "rapidly" and with large "quantity" (Palmer, 1964, p.111, cited from Day \& Bamford, 1998, p. 5). According to Hafiz and Tudor (1989):

"the pedagogical value attributed to extensive reading is based on the assumption that exposing learners to large quantities of meaningful and interesting L2 material will, in the long run, produce a beneficial effect on the learners' command of the L2" (p. 5).

Recent definitions however, have a more extended and elaborated definitions. These include the one given by Richards and Platt (2003) who state that: "extensive reading means reading in quantity and in order to gain a general understanding of what is read...... It is intended to develop good reading habits, to build up knowledge of vocabulary and structure, and to encourage a liking for reading" (p. 168). According to AlHomoud and Schmitt (2009), ER is "reading as much as possible, for the purpose of pleasure or information rather than learning particular language features" (p.383). Some researchers view extensive reading from a different angle. According to Emery (2009), ER: "is any reading that is done either for pleasure or not explicitly for the purposes of teaching reading" (p.38). ER in a second language (L2) has similar characteristics to that in the first language (L1) in that it is best if the book is self-selected by the reader (Day \& Bamford, 1998).

\subsection{Extensive Reading and Young Learners}

Learning to read in English can be a daunting task for any young reader. It is a "complex process of constructing meaning from text that involves linguistic knowledge, decoding processes at the letter and word levels, and higher order processes involving world knowledge, inference processes, and metacognitive strategies," (Brown \& Brewer, 1996, p. 263). Despite the fact that the majority of primary schools in the Middle East in general and in the Gulf and North African regions teach EFL, reading seems to be mainly taught to learn L2, no more. This issue apparently has negative effects on the young learners which is highlighted by Day and Bamford (1998) who point out that reading in the ESL/EFL classrooms bears very little resemblance to reading in the real world and many students who are: "learning to read a second language do not read and they do not like reading" (p.4). In the Middle East, there seems to be little interest to read for pleasure, especially in L2 (English) (Rajab \& Al-Sadi, 2015). As such, reshaping the pedagogical approaches in teaching EFL reading have to start with motivation to read and read extensively. Among the various teaching approaches to encourage the learners to maintain interest in learning English as an 
L2 is extensive reading (Brown, 2000). Day and Bamford (1998) define motivation as "what makes people do (or not do) something" (p.27). Deci and Ryan (1985) emphasize the intrinsic-extrinsic dichotomy of motivation. They define intrinsic motivation as: "motivation to engage in an activity because that activity in enjoyable and satisfying to do" whereas extrinsic motivation is related to: "actions carried out to achieve some instrumental end such as earning a reward or avoiding a punishment" (p.39). Learners with high intrinsic motivation tend to be high achievers and active readers (Guthrie et al., 2000) From the definitions of intrinsic and extrinsic motivation by Deci and Ryan, Day and Bamford (1998) formulated an L2 reading motivation model. The model has four essential variables: materials, reading ability, attitudes and sociocultural environment. In this study, materials and reading ability are the main variables taken into considerations.

\subsection{Graded Readers}

Selecting the appropriate materials for reading for young learners is of utmost importance since it will motivate them to read and read more. Thus, graded readers are the best choice for the reading enrichment programs such as the one adopted in this study and are mostly stories, which young learners mostly enjoy. Wright (1995) remarks: "Stories are particularly important in the lives of our children.... Children's hunger for stories is constant" (p.5). Graded readers are books (or stories) written for L2 learners to improve their linguistic competence (Waring, 2002). The term 'graded' refers to the proficiency level grading (reader's level of L2 proficiency) of books or stories. Graded readers are designed in such a manner so as to perfectly suite the comprehension level of the reader. "The vocabulary at each level is established by reference to recent corpus-based lexical research, analysis of commonly-occurring words in course materials and readers, and the Council of Europe's Waystage and Threshold levels (Prowse, 1999). Similarly, the grammar levels of the graded readers are also simplified to match the proficiency level of the reader for better comprehension (Waring, 2002). Providing L2 learners with graded readers that match their proficiency level leads to increased intrinsic motivation (Dawson, 2002; Nishino, 2005).

\section{The Conceptual Framework}

The study is framed within Krashen's (1989) Input Hypothesis (also known as the monitor model), which maintains that: "we acquire language by understanding messages, that 'comprehensible input' is the essential ingredient in language acquisition" (p. 440). In the extended version of this hypothesis, the natural approach, Krashen believes that an L2 learner can acquire an " $i+1$ " proficiency level (where ' $i$ ' represents the current level the learner is at and ' $i+1$ ' is the next proficiency level up) provided the conditions are favourable to understand the ' $i+1$ ' message (Krashen \& Terrell 1983, p.32). However, some researchers have expressed their disagreement to the " $i+1$ " principal and proposed a counter argument in the form of " $\mathrm{i}-1$ " approach where the L2 learner is better exposed to L2 materials that are slightly lower than their actual proficiency level where " $i+1$ " complications are limited or non-existent (Day and Bamford, 1998). In this study, the researchers adopted both principals where the young learners were exposed to the " $i-1$ " graded readers and as they progressed further, the " $i+1$ " was followed suit. Additionally, this study also adopts the social 
constructivists' view which has been generally informed by the theories of Piaget (1973), and von Glaserfeld (1984), as well as the social constructivist's theory of Vygotsky (1978). Even though young learners may experience a sense of control and autonomy when choosing the graded readers titles they wish to read where a higher mental functions are operating, extensive reading as well as writing, there are other significant individuals (knowledgeable others) who play a pivotal role in this. Those knowledgeable others may include: teachers, parents, older siblings, even peers who have experienced the same situation before. They can all provide social context in which the child's cognitive functions develop (Vygotsky, 1978). As a literacy activity, extensive reading is best accomplished in the discourse of the classroom as well as at home with the learner's family and the larger society through the interactions that take place (Diamond \& Moore, 1995).

\subsection{Research Objectives and Questions}

The current study has two main aims. The first and general aim is to investigate whether or not ER has a positive outcome on improving the L2 proficiency levels of the participating young learners in general and their reading and writing abilities in particular. The second and specific aim is to try to examine if ER has a positive effect on those participants in developing love for reading in L2. Thus, the study attempted to answer the following main research question:

Does ER improve the L2 proficiency levels reflected in pre and post-tests grades of young EFL learners at three international schools in two countries, Saudi Arabia and Egypt?

Several null hypotheses were developed for this study. These are:

i. $\quad \mathrm{H} 0=$ There is no significant difference between all the groups' results following the entrance test.

$\mathrm{H} 1=$ There is a significant difference between all the groups' results following the entrance test.

ii. $\mathrm{H} 0=$ There is no significant difference between the groups' grades in Egypt in both entrance and exit tests.

$\mathrm{H} 1=$ There is a significant difference between the groups' grades in Egypt in both entrance and exit tests.

iii. $\mathrm{H} 0=$ There is no significant difference between the experimental group's grades in Saudi Arabia in both entrance and exit tests.

$\mathrm{H} 1=$ There is a significant difference between the experimental group's grades in Saudi in both entrance and exit tests.

iv. $\mathrm{H} 0=$ There is no significant difference between all the groups' results following the exit test.

$\mathrm{H} 1=$ There is a significant difference between all the groups' results following the exit test. 
v. $\mathrm{H} 0=$ There is no significant difference between experimental groups' grades and the control groups' grades following the exit test.

$\mathrm{H} 1=$ There is a significant difference between experimental groups' grades and the control groups' grades following the exit test.

\subsection{Rationale for the Study}

Despite the fact that several studies have been carried out in the Middle East on ER (Al-Mulla, 2007; Al-Homoud and Schmitt 2009; Roscoe \& Al-Mahrooqi, 2013; Al-hajji \& Shuqair, 2014), the main focus of these studies is either on adult (tertiary level learners) or on variables not related to ER. Perhaps it is the fact that research involving young learners is very complex and requires lengthy preparations and obtaining various ethical approvals from numerous bodies as well as obtaining parental/guardian consents to participate in the research. This study was conducted with minimal contact and involvement (if any) between the researchers and the young learners (participants) as will be explained later. The study aimed at contributing to the growing body of literature concerned with second language acquisition (SLA) in EFL young learners in general and the effect ER intervention programs may have on those learners. Provided the results of this study are positive and conditions are favourable, primary schools in the Middle East and even worldwide may adopt a similar idea or even adapt a different approach of the main idea of this research.

\section{The Study}

This study adopted a quasi-experimental, longitudinal, quantitative methods where the main focus was on investigating the impact of Extensive Reading (ER) on developing second language (L2) reading comprehension and writing skills among primary school EFL learners in two Arab countries, Egypt and Saudi Arabia. The actual nature of the procedures followed in this study are quite straightforward. The researchers, following obtaining ethical approvals from the three schools as well as the consents from the parents/guardians of the participating students, divided the study into basically three consecutive durational steps. The first step was to collect grades of the L2 proficiency entrance tests designed by the schools themselves for all the participants in the five groups. The second step was to deliver graded readers to the primary schools' teachers to distribute them amongst their students. The third and final step was to collect grades of the L2 proficiency exit tests, which are also designed and administered, by the schools. Both entrance and exit tests included reading as well as writing elements integrated into them. No direct contact was made with any of the participants and no direct intervention, observations or interviews whatsoever were made with the young learner participants. The purpose of the latter decision (i.e. to have minimal or no contact at all with the participants) was made in order to exclude any concerns or objections to the study from various individuals as well as to minimize researchers' bias, which can easily occur in research studies with young learners. Additionally, the directives instructed to the elementary teachers assisting in this study, that during the distribution of the graded readers to the young learners, they should inform them that there would be no homework, tests or quizzes and non-participation in this program is not penalised in any way or form. Furthermore, the researchers decided to encourage the young learners to participate in this program by offering 
them the third graded reader they choose for free (once they have read and completed two titles). This way, an external motivation is initiated and in the hope it will lead to intrinsic motivation (Deci \& Ryan, 1985; Sansone \& Harackiewicz, 2000).

\subsection{Participants}

The participants were $112(n=112)$ young learners at three international schools registered at grade 2 in both countries (Egypt and Saudi Arabia). All the participants were of 7 years of age; spoke Arabic as their L1 and they were of mixed genders, male and female young learners. The five groups were designated corresponding codes. These codes are:

G1EEB: Group 1, Experimental Egypt pre-test. (23 students)

G2EEB: Group 2, Experimental Egypt pre-test (23 students)

G3CEB: Group 3, Control Egypt pre-test (22 students)

G4ESB: Group 4, Experimental Saudi pre-test (23 students)

G5CSB: Group 5, Control Saudi pre-test (21 students)

G1EEA: Group 1, Experimental Egypt post-test (23 students)

G2EEA: Group 2, Experimental Egypt post-test (23 students)

G3CEA: Group 3, Experimental Saudi post-test (22students)

G4ESA: Group 4, Experimental Saudi post-test. (23 students)

G5CSA: Group 5, Control Saudi post-test. (21 students)

\subsection{Instrument}

The instruments used in this study were solely the selected graded readers from Cambridge University Press ${ }^{\circledR}$ (CUP). The collection was carefully chosen to meet the EFL context of Egypt and Saudi Arabia and duplicated copies of the graded readers were available in case some learners wanted to select the same reader. Following the ethical approvals obtained from the schools and the consent forms from the parents/guardians, the graded readers were distributed to all experimental groups (barring the control groups, groups 3 and 5) in both countries. The titles distributed in the two countries were identical so as to keep consistency and coherence of the data obtained and prevent any imbalances or discrepancies due to variations in levels and type of graded readers given.

\subsection{Data Collection and Analysis}

The main data collection occurred at the beginning of the school year (September) where the entrance exam grades of all the groups were entered into SPSS $^{\circledR} 22$. Descriptive as well as inferential statistical analysis tests in the form of t-tests as well as one way ANOVA tests were carried out to determine if significant differences existed among the groups prior to the ER enrichment program. Following the program, the exit exam grades of all the groups were also collected and subjected to a mixture of descriptive statistics as well as extensive 
inferential statistical analysis tests between experimental groups after the implementation of the ER enrichment program as well as between the groups pre and post implementation of the ER enrichment program. Reliability test was carried out in the form of Cronbach's Alpha using SPSS ${ }^{\circledR} 22$ once all the grades (entrance and exit tests scores) were obtained.

\section{Findings and Results}

The results obtained from the data analysis provided some interesting insights and key findings for analysis.

Following the gathering of the participants' tests scores, a reliability test in the form of Cronbach's Alpha was carried out and the result of the test was 0.746 and 0.776 on the standardized items as shown below in table 1 .

Table 1. Cronbach's Alpha reliability test

\section{Reliability Statistics}

\begin{tabular}{|c|c|c|}
\hline Cronbach's Alpha & Cronbach's Alpha Based on Standardized Items & N of Items \\
\hline .746 & .776 & 10 \\
\hline
\end{tabular}

A one way ANOVA was performed in order to determine if there were any significant difference between all the groups following the entrance tests administered by the schools. The result of $F=0.554$ and $p=0.697$ indicated that there was no significant difference between the results of the participants in the six groups following the entrance tests. Since the $p$ value is $>0.05$, we retain the first null hypothesis. The results are illustrated in table 2 .

Table 2. One way ANOVA test for significance between the groups following the entrance tests

ANOVA

\begin{tabular}{|c|c|c|c|c|c|c|}
\hline & & $\begin{array}{l}\text { Sum of } \\
\text { Squares }\end{array}$ & $\mathrm{df}$ & $\begin{array}{l}\text { Mean } \\
\text { Square }\end{array}$ & $\mathrm{F}$ & Sig \\
\hline \multicolumn{2}{|c|}{ Between People } & 1508.440 & 19 & 79.392 & \multirow{6}{*}{.554} & \multirow{6}{*}{.697} \\
\hline Within & Between & 56540 & 4 & 14135 & & \\
\hline \multirow[t]{3}{*}{ People } & Items & 50.540 & 4 & 14.155 & & \\
\hline & Residual & 1939.860 & 76 & 25.524 & & \\
\hline & Total & 1996.400 & 80 & 24.955 & & \\
\hline Total & & 3504.840 & 99 & 35.402 & & \\
\hline
\end{tabular}

With regards to the two experimental groups in Egypt, the experimental group in Saudi, the control group in Egypt and the control group in Saudi, a paired samples t-test was performed on all these groups following the entrance tests and the exit tests. The results of these paired 
samples t-tests indicate that there are significant difference in the experimental groups' grades the pre and post implementation of the enrichment ER program. The results also indicated that there were no significant difference between the control groups in both Egypt and Saudi Arabia pre and post implementation of the enrichment ER program. Thus, we reject the second and third null hypotheses since there are significant difference between the experimental groups pre and post implementation of the enrichment ER program and retain the fifth null hypothesis since there are no significant differences between the control groups' grades in both Egypt and Saudi Arabia. The results are illustrated in table 3.

Table 3. Paired Samples t-tests.

\section{Paired Samples Test}

\begin{tabular}{|c|c|c|c|c|}
\hline & & $\mathrm{t}$ & $\mathrm{df}$ & Sig. (2-tailed) \\
\hline Pair 1 & $\begin{array}{l}\text { Group } 1 \text { Experimental - } \\
\text { Egypt - Before - Group } 1 \\
\text { - Experimental - Egypt - } \\
\text { After }\end{array}$ & -4.628 & 21 & .000 \\
\hline Pair 2 & $\begin{array}{l}\text { Group } 2 \text { Experimental - } \\
\text { Egypt - Before - Group } 2 \\
\text { Experimental - Egypt - } \\
\text { After }\end{array}$ & -4.061 & 21 & .001 \\
\hline Pair 3 & $\begin{array}{l}\text { Group } 4 \text { - Experimental - } \\
\text { Saudi Arabia - Before - } \\
\text { Group } 4 \text { - Experimental - } \\
\text { Saudi Arabia - After }\end{array}$ & -9.825 & 21 & .000 \\
\hline Pair 4 & $\begin{array}{l}\text { Group } 3 \text { Control - Egypt - } \\
\text { Before - Group } 3 \text { - } \\
\text { Control - Egypt - After }\end{array}$ & -1.975 & 20 & .062 \\
\hline Pair 5 & $\begin{array}{l}\text { Group } 5 \text { - Control - Saudi } \\
\text { Arabia - Before - Group } 5 \\
\text { - Control - Saudi Arabia - } \\
\text { After }\end{array}$ & -1.157 & 19 & .262 \\
\hline
\end{tabular}

With regards to the one way ANOVA test to compare the results of all the groups post implementation of the enrichment ER program, the analysis indicate that at $F=12.903$ and $\mathrm{p}<0.05$, we can reject the fourth null hypothesis since there is a significant difference between the groups. The results are indicated in table 4 . 
Table 4. One-way ANOVA for all the groups' grades following the implementation of the enrichment ER program.

\begin{tabular}{|c|c|c|c|c|c|c|}
\hline \multicolumn{7}{|c|}{ ANOVA } \\
\hline & & $\begin{array}{l}\text { Sum of } \\
\text { Squares }\end{array}$ & df & $\begin{array}{l}\text { Mean } \\
\text { Square }\end{array}$ & $\mathrm{F}$ & Sig \\
\hline \multicolumn{2}{|c|}{ Between People } & 1437.640 & 19 & 75.665 & \multirow{6}{*}{12.903} & \multirow{6}{*}{.000} \\
\hline Within & Between & 2666.140 & 4 & 666.535 & & \\
\hline \multirow[t]{3}{*}{ People } & Items & & & & & \\
\hline & Residual & 3925.860 & 76 & 51.656 & & \\
\hline & Total & 6592.000 & 80 & 82.400 & & \\
\hline Total & & 8029.640 & 99 & 81.107 & & \\
\hline
\end{tabular}

\section{Conclusion}

From the results and the statistical analysis results obtained, it can be seen that the enrichment ER program had a positive effect on the L2 proficiency levels of the participants in the experimental groups. This is quite evident in the results of the inferential statistical tests, the paired samples t-tests and the one way ANOVAs.

To answer the main research question of this study and that is whether an enrichment ER program can improve the L2 proficiency level of young learners, we can confidently say that this study has proven that it can. The young learners who have had the opportunity to be exposed to an ER enrichment program (experimental groups in Egypt and Saudi Arabia) where graded readers were appealing and interesting to them, had the advantage to improve their L2 proficiency levels compared to those who did not (the control groups). The experience has proven to be a positive one, based on the anecdotal reporting of the teachers who reflected upon the enthusiasms and motivations of the young learners to engage in reading.

This study concludes with certain views, which in essence, are related to the exposure of young EFL learners to sufficient and suitable materials. Furthermore, starting English early in an EFL context such as Egypt and Saudi Arabia has no advantage unless the young learners are exposed to massive text input since they have limited chances of L2 interactions outside the classroom boundaries. This does not go without saying that few of the teachers who assisted in this research informed us of relapses few young learners had due to the fact that there were no follow up initiative following the ER enrichment program. In brief, reading, as a major L2 skill, needs to be reconsidered in the EFL context in general and in the EFL for young learners in particular. There has to be an established vision of promoting ER in young learners so as to successfully lead them to gain self-efficacy and self-confidence later on in their academic lives. Additionally, primary schools need to eradicate the occurrences of any early reading failures since those failures build a sense of 'learned helplessness' where the young learner feels a lack of control and disconnection (Decker \& Buggey, 2013; Jesson \& Limbrick, 2014). 


\section{Recommendations for Future Research}

The researchers of this study hope that this research study will contribute to a growing compendium of literature aimed at developing a much wider and deeper understanding of the benefits and advantages of ER enrichment programs in EFL young learners. The results presented in this study demonstrate the success with which an ER enrichment program can lead to in EFL young learners. However, it would be recommended to have parallel research studies confirm these results especially if carried out on a larger scale and different EFL contexts.

\section{Acknowledgments}

We would like to thank all the primary schools and guardians of the elementary students at those schools for agreeing to allow their dependents to participate in this study. Special thanks are extended to the primary schools' teachers who assisted tirelessly in carrying out this research. We would also like to thank Mr. Warren Ritson and Julian Eynon from Cambridge University Press ${ }^{\circledR}$ for providing us with the titles for this study from Cambridge Young Readers and Cambridge Storybooks.

\section{References}

Alderson, J. C. (1984). 'Reading in a foreign language: a reading problem or a language problem?' In J. C. Alderson and A. H. Urq'uhart (eds.), Reading in a Foreign Language. London: Longman

Alhaqbani, A., \& Riazi, M. (2012). Metacognitive awareness of reading strategy use in Arabic as a second language. Reading in a Foreign Language, 24(2), 231-255.

Al-hajji, B. A., \& Shuqair, K. M. (2014). A Systematic Review on Using Literature for the Young Learners in an EFL Classroom. English Language Teaching, 7(8), 75.

Al-Homoud, F., \& Schmitt, N. (2009). Extensive reading in a challenging environment: A comparison of extensive and intensive reading approaches in Saudi Arabia. Language Teaching Research, 13(4), 383-401.

Al Mulla, K. (2007). Developing young learners' reading skills in an EFL classroom. Action Research and Initial Teacher Education in the UAE. Online article. Accessed, January 20th, 2015. http://marifa.hct.ac.ae/2007/725

Allor, J. H., Mathes, P. G., Roberts, J. K., Cheatham, J. P., \& Al Otaiba, S. (2014). Is scientifically based reading instruction effective for students with below-average IQs? Exceptional Children, 80(3), 287-306.

Bamford, J., \& Day, R. R. (2004). Extensive reading activities for teaching language. Cambridge, England: Cambridge University Press.

Barnette, M.A. (1989). More than Meets the Eye: Foreign Language Reading Theory and Practice. New Jersey: Prentice Hall.

Beglar, D., Hunt, A., \& Kite, Y. (2012). The effect of pleasure reading on Japanese EFL 
learners' reading rates. Language Learning, 62, 665-703.

http://onlinelibrary.wiley.com/doi/10.1111/j.1467-9922.2011.00651.x/abstract

http://dx.doi.org/10.1111/j.1467-9922.2011.00651.x

Bell, T. (2001). Extensive reading: Speed and comprehension. The Reading Matrix, 1(1).

Brown, R. (2000). Cultural continuity and ELT teacher training. ELT Journal, 54(3), 227-234.

Carrell, Scott E., Carrell, Susan A., 2006. Do lower student to counselor ratios reduce school disciplinary problems? Contrib. Econ. Anal. Policy 5 (1), Article 11.

Carrell, P. L. (1995). Introduction: Interactive approaches to second language reading. In P. L. Carrell, J. Divine, and D. E. Eskey. (Eds.), Interactive Approaches to Second Language Reading. (pp. 1-7). Cambridge, Cambridge University Press.

Day, R. R., \& J. Bamford. (1998). Extensive reading in the second language classroom. Cambridge: Cambridge University Press.

Dawson, N. (2002, February 15). Jogging to language competence. The Language Teacher. Retrieved May 20, 2015, from http://www.jalt-publications.org/tlt/articles/2002/11/op1

Decker, M. M., \& Buggey, T. (2014). Using video self-and peer modeling to facilitate reading fluency in children with learning disabilities. Journal of learning disabilities, 47(2), 167-177.

Diamond, B., \& Moore, M. A., (1995). Multicultural literacy: Mirroring the reality of the classroom. New York: Longman.

Elley, W. B. \& Mangubhai, F. (1983). The impact of reading on second language learning. Reading Research Quarterly, 19, 53-67.

Gates, A. I. (1949). Character and Purpose of the Yearbook in Reading in the Elementary School. Henry B. Nelson Ed., The Forty-eighth Yearbook of the National Society for the Study of Education University of Chicago Press, Chicago.

Grabe, W. (2010). Fluency in Reading--Thirty-Five Years Later. Reading in a foreign language, 22(1), 71-83.

Guthrie, J. T., Cox, K.E., Knowles, K.T., Buehl, M., Mazzoni, S., \& Fasculo, L. (2000) Building toward coherent instruction. In L Baker, J. Dreher, \& J.T. Guthrie (Eds.), Engaging young readers: Promoting achievement and motivation (pp. 209-237). New York: Guilford.

Hafiz, F. M., \& I. Tudor (1990). Graded Readers as an Input Medium in L2 Learning. System $18,1: 31-42$.

Hedgcock, J., \& D. Atkinson. (1993). Differing Reading Writing Relationships in L1 and L2 Literacy Development? TESOL Quarterly, 27(2), 329-33.

Hedge, Tricia. (2003). Teaching \& learning in the language classroom. UK: OUP.

Holden, J. (2004). Creative Reading: Young people, reading and public libraries. London: Demos. 
Iwahori, Y. (2008). Developing Reading Fluency: A Study of Extensive Reading in EFL. Reading in a Foreign Language, 20(1), 70-91.

Janopoulos, M. (1986). The relationship of pleasure reading and second language writing proficiency. TESOL quarterly, 20(4), 763-768.

Jesson, R., \& Limbrick, L. (2014). Can gains from early literacy interventions be sustained? The case of Reading Recovery. Journal of Research in Reading, 37(1), 102-117.

Koch, (1974). Relationships between reading interests and reading comprehension among fourth-grade and sixth-grade students. Unpublished Doctoral Dissertation, University of Illinois at Urban-Champaign, IL, USA.

Krashen, Stephen D., \& Tracy D. Terrell. (1983). The natural approach: Language acquisition in the classroom. Hayward, CA: Alemany Press.

Krashen, S. (1993). The Power of Reading. Englewood, Col.: Libraries Unlimited, Inc

Krashen, S. (2004). The Power of Reading. Portsmouth: Heinemann and Westport: Libraries Unlimited.

Lyon, B., \& Weiser, G. R. (2009). Teacher knowledge, instructional expertise, and the development of reading proficiency. Journal of learning disabilities, 42. 475-480.

Lyons, C. A. (2003). Teaching Struggling Readers. Portsmouth, New Hampshire. Heinemann.

Mason, B., \& Krashen, S. (1997). Extensive reading in English as a foreign language. System, 25(1), 91-102.

McLaughlin, B. (1987). Theories of second language learning. London: Edward Arnold.

Mikulecky. B., \& Jeffries. L. (1986). Reading Power. Addison-Wesley Publishing Company.

Mokhtari, K., \& Reichard, C. (2004). Investigating the strategic reading processes of first and second language readers in two different cultural contexts. System: An International Journal of Educational Technology and Applied Linguistics, 32(3), 379-394.

Nakanishi, T. (2005). A book in question! Intertwining receptive and productive skills using graded readers. The Language Teacher, 29(6), 35-36.

Nation, I. S. P. (1997b). The language learning benefits of extensive reading. The Language Teacher, 21(5), 13-16.

Nishino, T. (2005). Japanese high school students' L2 reading motivation. Lifelong Learning: Proceedings of the 4th Annual JALT Pan-SIG Conference. Retrieved January 20, 2015, from http://www.jalt.org/pansig/2005/HTML/Nishino.htm

Piaget, J. (1973). To understand is to invent: The future of education. New York: Grossman.

Prowse, P. (1999). Cambridge English Readers - Teacher's Guide. Cambridge University Press, UK. 
Pugh, S. L., Pawan, F., Antommarchi, C. (2000). Academic literacy and the new language learner. In R. F. Flippo D. C. Caverly (Eds.), Handbook of college reading and study strategy research (pp. 25-42). Mahwah, NJ: Erlbaum Publishers.

Rajab, H., \& Al-Sadi, A. (2015). An Empirical Study of Reading Habits and Interests of Saudi University EFL Learners. International Journal of Linguistics, 7(2), pp-1. http://dx.doi.org/10.5296/ijl.v7i2.7034

Rasinski, T. V., \& Hoffman, S. (2003). The fluent reader: Oral reading strategies for building word recognition, fluency, and comprehension. New York: Scholastic.

Richards, J. C., Platt, J., \& Platt, H. (1999). Longman dictionary of language teaching and applied linguistics. Essex: Longman.

Ritchie, S. (2014). Iran: Strong early reading predict high IQ later. Asia news monitor. http://english.farsnews.com/newstext.aspx?nn=13930505000228

Robb, T. N., \& Susser, B. (1989). Extensive reading vs. skills building in an EFL context. Reading in a foreign language, 5(2), 239-251.

Roe, B., Smith, S., \& Burns, P. C. (2011). Teaching reading in today's elementary schools. Cengage Learning.

Roscoe, A., \& Al-Mahrooqi, R. (Eds.). (2013). Focusing on EFL reading: Theory and practice. Muscat, Oman: Sultan Qaboos University Press.

Ryan, R. M., \& Deci, E. L. (2000). Intrinsic and extrinsic motivations: Classic definitions and new directions. Contemporary educational psychology, 25(1), 54-67.

Sansone, C., \& Harackiewicz, J. M. (Eds.). (2000). Intrinsic and extrinsic motivation: The search for optimal motivation and performance. Academic Press.

Thomlinson, J. (2007). What are graded readers? Thomson Graded Readers Series.

Tsang, W. (1996). 'Comparing the Effects of Reading and Writing on Writing Performance.' Applied Linguistics. Volume 17, Number 2.

Von Glaserfeld, E. (1984). An introduction to radical constructivism. In P. Watzlawick (Ed.), The Invented Reality (pp. 1740). New York: Norton.

Vygotsky, L. S. (1978). Mind in society: The development of higher psychological processes. (M. Cole, V. John Steiner, S. Scribner, \& E. Souberman, Eds. \& Trans.). Cambridge, MA: Harvard University Press.

Waring, R. (2002). The 'Why' and 'How' of using graded readers. Okayama: Notre Dame Seishin University.

Weaver, C. (2002). Reading process and practice (3rd edition). Portsmouth, NH: Heinemann Educational Books.

Wright, A. (1995). Storytelling with Children, Oxford University Press. 


\section{Macrothink

Yu, V., \& C. Wong. (1991). 'The Hong Kong Extensive Reading Scheme (HKERS) - an extensive reading program for junior secondary school students'. Institute of Language in Education Journal, 8, 188-92.

\section{Copyright Disclaimer}

Copyright for this article is retained by the author(s), with first publication rights granted to the journal.

This is an open-access article distributed under the terms and conditions of the Creative Commons Attribution license (http://creativecommons.org/licenses/by/3.0/). 